\title{
Adrian Hielscher \\ Four-Legged Marble Tables (mensae) in Pompeian Houses: The Intersection of Function, Aesthetics and Semantics
}

\begin{abstract}
In this paper, marble will be considered outside of its use in architecture through the examination of a special case study: four-legged tables, or mensae from the Vesuvian area. This type of furniture is of particular interest for two reasons. First, its form was originally designed for a different material (wood) and transferred to marble afterwards, meaning that form and material were not initially coordinated. Second, these pieces of furniture are embedded in different contexts and actions inside a household. Consequently, these marble tables constituted an important focal point within Pompeian houses. Here, this small group of objects will be analysed on the basis of its interplay with materiality. This analysis will be based on a theoretical concept of dividing the aesthetics, semantics and function of the material substance, but without prioritising any of these three aspects. The basic assumption of this contribution is that depending on the analytical perspective, the spatial context and the ancient situation, different qualities of the material come into play. Consequently, it would be wrong to reduce the qualities of marble down to one single aspect, for example its nonverbally communicated economic value (semantics).
\end{abstract}

\section{Function, Aesthetics and Semantics: The Qualities of Material Substances and Objects}

In recent years, a new basic and systematic understanding of objects has been developed in the humanities. In accordance with the central methodological concept of the 'Materiality as Decor' conference, this paper considers the function, aesthetics and semantics ${ }^{1}$ of a specific material, namely marble ${ }^{2}$. But materials in general only reveal these qualities when they are shaped into an object ${ }^{3}$. Consequently, material properties become object properties to a certain extent $t^{4}$. The form of an object is partially bound to the choice of material and vice versa, due to the physical properties of each material and the manufacturing techniques employed. However, before the relationship between the aesthetics, function and semantics of marble can be explained with reference to a concrete category of objects (mensae), these qualities must be briefly defined.

Function: Physical properties such as form, size and material are mostly determined by the purpose for which objects were produced. Furniture, tools, vessels and other objects for daily use are created to satisfy pragmatic needs. These objects had to function. At this point, the term 'function' is used exclusively to describe the practical usage of things ${ }^{5}$. The physical presence of these

1 In contrast to the title of this conference volume, the order of these qualities has been changed. In this paper, 'function' is considered first, because the materiality of mensae is understood primarily within the contexts of action and use.

2 On function, aesthetics and semantics as three basic qualities of 'things' and as parts of Roman object design, see Hielscher, forthcoming.

3 Wagner 2005, 867; Raff 2008, 13; Haug - Hielscher, this volume.

4 On these three object qualities or 'thing properties' (Dingeigenschaften) in material culture studies and design theory, see Hartmann - Haubl 2000, 9 f.; Hahn 2005, 26-144; Böhme 2016, 44-46; Heufler 2016, $27-58$.

5 Another type of function is an object's culturally constructed one. This cannot be deduced directly from the object and it can change over time: see Fox et al. 2015, 67; Swift 2017, 6. It describes the cultural handling of things in the sense of a secondary function. In order to be able to grasp this, archaeological contexts as well as written and visual sources must be included. 
things creates a diverse range of possible actions for using them ${ }^{6}$. This relationship between the physical properties of an object and the capacity of an actor can be referred to as 'affordance'. Affordances do not simply comprise the absolute attributes of objects, but rather the sum of all possible forms of interaction between subject and object ${ }^{7}$. In the case of precious objects decorated with numerous ornaments and images, the functional aspect often takes a back seat. They are treated in research as luxury objects or carriers of images ${ }^{8}$, which is a very simplistic, one-dimensional interpretation. The choice of a (more or less) appropriate material is particularly important because it is directly connected to the usability of an object. Materials make things light or heavy, hard or soft, rough or smooth and so on. The material affects the object's manageability as well as its resistance to external conditions. But finally, neither things nor materials can be reduced exclusively to their usability 9 .

Aesthetics: This quality brings together all of the sensually perceptible properties of things that have no effect on their function or meaning ${ }^{10}$. Every object has an 'aesthetic presence' (ästhetische Präsenz $)^{11}$. It is possible for a beholder to have an 'aesthetic experience' ${ }^{12}$ through an object. However, to differentiate an everyday object from our general perception (Mitwahrnehmung) ${ }^{13}$, sensually perceptible markers are required. Such markers include single- or multi-coloured surfaces, texture, transparency, and the shine of objects. All these visual characteristics emerge specifically from the material. Consequently, material affects the 'aesthetic experience' that we can have with objects.

In aesthetic theory, different varieties of aesthetic perception have been distinguished. Of these, the most important and comprehensive modes of aesthetic perception are 'contemplation' (Kontemplation) $)^{14}$ and 'impressive experience' (impressives Ausdruckserleben) ${ }^{15}$. A 'contemplative perception' excludes all functional or symbolic ascriptions to the object in the outside world ${ }^{16}$. The observer loses him- or herself in the act of perception ${ }^{17}$, to the point where the course of

6 Erlhoff - Marshall 2008, 154; Keßeler 2016, $346 \mathrm{f}$.

7 On affordance in perception- and design-theory, see Gibson 1966, 266-286; Knappett 2004, 43-51; Norman 2013, 1013; for its role in archaeology, see Swift 2014, 203; 2017, 5; Fox et al. 2015, 63-70; Keßeler 2016, 347; Plant, this volume. 8 On marble objects as a form of luxury consumption, see Wallace-Hadrill 2008, 356-440; Lapatin 2015, 321-342; Sinn 2015, 301f.; explicitly concerning marble tables, see Richter 1966, 110; Cohon 1984, 7.

9 Böhme 2016, 44-46.

10 Concepts drawn from aesthetic theory from the late $20^{\text {th }}$ and early $21^{\text {st }}$ centuries are suitable for approaching ancient material culture. Neither during postmodernism nor in antiquity was there a dogmatic concept of 'art' like that established during the early Modern period. Technical innovations and growing standards in the reproduction of (art-) objects, as well as the rise of new media for their depiction resulted in a dissolution of the conventional paradigms of 'art'. The terms 'art' and 'artwork' disappeared in their traditional understanding, just like the classical dichotomy between art and everyday life, or rather between artwork and everyday objects (see Marcel Duchamp's 'Readymades', 1913-1917). In postmodern art, and consequently in art philosophy and art theory, there arose a conceptual interconnectedness of everyday life and art: see Liessmann 1999, 97-121. 149-158; Kleimann 2002, 160-170; Beer 2018, 69-77. Concerning the non-existence of 'art' in antiquity, see Debray 2007, 151-171. On the (Greek and Roman) concept of so-called art in classical archaeological research, see Borg 2015, 2-4. Hallett (2015) tried to define 'Roman art', showing, amongst other things, that it is a modern construct based on an appreciation of periods and styles rather than a concept that was understood at the time by contemporary society. Hallett $(2015,22$. 29-31) argues for a concept of 'visual culture' instead of 'art'.

11 Seel 1996, 48.

12 The 'aesthetic experience' has been developed as an overarching concept in the aesthetic theory of recent decades, and is used to describe visual qualities of art, nature or everyday life. For a summary of the numerous attempts to define aesthetic experience, see Kleimann 2002, 52-55; Brandstätter 2012, 174; Fuchs 2015; Lehmann 2016.

13 On this phenomenon of unspecific, undirected, inattentive aesthetic perception in everyday life, see Kleimann 2002, $81 \mathrm{f}$.

14 Kleimann 2002, 94-101.

15 Kleimann 2002, 101-113.

16 Kleimann 2002, 95.

17 Seel 1996, 48; Gumbrecht 2003, 203-222; Brandstätter 2012, 176. 
time ${ }^{18}$ and the surrounding space disappear. In contrast, the realisation of the impression that an object leaves with us can be described as an 'impressive experience'. Gernot Böhme therefore uses the phrase 'ecstasies of the things' (Ekstasen der Dinge) ${ }^{19}$ to characterise a mode of the 'aesthetic presence' (atmosphärische Gegenwärtigkeit) of objects. 'Contemplation' and 'impressive experience' both describe a kind of pure attention given to an object and its sensuality, without applied knowledge or intentional will. Shapes, ornaments, images and especially the material of an object, with its colour and surface effects, are the elements of this aesthetic experience ${ }^{20}$. No previous stock of knowledge, norms or experiences are therefore required for this experience to take place ${ }^{21}$. It is all about the interplay of appearance and the purely sensual experience of the things.

Semantics: In addition to aesthetic or functional reasons for choosing particular materials, the latter can also be selected or combined because they have specific semantic qualities ${ }^{22}$. Design theory refers to the connection between semiotics and object design as the creation of a 'product language' (Produktsprache). The term 'product language' means that in addition to practical functions being derived from the physical aspects of an object and aesthetic functions being derived from the sensual aspects of an object, actual design elements (such as materials) can also be understood semantically ${ }^{23}$. Consequently, the material design of objects offers symbolic meanings which can be comprehended or interpreted by the observer ${ }^{24}$. These significations are not native properties of the material substance, but are rather (socio-) cultural ascriptions produced by the viewers themselves.

Like images and other non-verbal signs, objects and materials are polysemic ${ }^{25}$. They are carriers of meanings (Semiophoren) and can also be classified as 'imprecise signs' (unscharfe Zeichen) ${ }^{26}$. Furthermore, a material's meaning cannot not be interpreted in a blanket way but is rather activated in certain situations or social contexts ${ }^{27}$. Material can be 'semantically charged', 'de-charged' and 're-charged' over time ${ }^{28}$. For example, a specific material can be assigned to certain milieus, social classes or social identities ${ }^{29}$. The materiality of things could thus symbolise social or cultural conceptual worlds ${ }^{30}$. This signification attached to material becomes concrete when we consider how some unpretentious objects have been classified as prestigious or luxury goods because of their precious materials ${ }^{31}$.

The material substance is related to its usability, but this affects the aesthetic appearance and meaning of an object ${ }^{32}$. The three object properties outlined above always occur simultaneously. They are closely interwoven, inseparable, and can also merge with one another ${ }^{33}$. Precisely which

18 This timelessness experienced during aesthetic perception is described by Seel $(1996,50)$ as 'Modus des Verweilens', by Iser (2003, 176-202) as 'Gegenwart des Ästhetischen' and by Mersch (2001, 273-300) as 'Sensibilität des Augenblicks'.

19 Böhme 1995, 32-34; Kleimann 2002, 107-112.

20 Böhme 1995, 51-56.

21 Maase 2007, 89-93.

22 Hahn 2003, 29-51; 2015, 31 f.; Scholz 2019, 20.

23 Steffen 2000, 6-8; Heufler 2016, 23-25. 33-35; Reinhardt 2018, 7 f.

24 Bürdek 2015, 148-154; Heufler 2016, 46 f.; Reinhardt 2018, 7 f. 15.

25 Hodder 1989, 250-269; Hahn 2003, 29-51; 2005, 137-142; Kienlin 2005, 6 f.

26 Hahn 2005, 122-129.

27 Raff 2008, 14. $22 \mathrm{f}$.

28 Raff 2008, 15.

29 Bosch 2014, 75; Swift 2014, 203.

30 Kienlin - Widura 2014, 31-38; Heufler 2016, 33 f. For example, on the magic and healing capabilities of materials, see Raff 2008, 42-46. On the use of certain materials as historical references, including the use of spolia, see Raff 2008, 83-87.

31 See Haug - Hielscher, this volume. On the relationship between semiotics, status symbols and prestigious goods in archaeology, see e. g., Burmeister 2009, 73-102; Hildebrandt et al. 2014, 237-240.

32 The same applies to an object's form, ornament and images: see Hielscher, forthcoming.

33 Hahn 2005, 117; Böhme 2016, 44-46. 
aspect of materiality is perceived depends upon the context of the object, the particular circumstances of action and the disposition of the subject ${ }^{34}$. This will be discussed in detail below using the example of the marble tables. Prior to that discussion, this group of objects, known as mensae, will be briefly introduced.

\section{Mensae: A Short Definition, the Development of the Type and their Intermateriality}

Mensae are a special type of Roman marble table ${ }^{35}$. They are characterised by the construction of their four legs, each of which had a rectangular base and decoration on the outward-facing side (Fig. 1). The legs consist of three areas: an upper end ('capital') which could carry ornamental motifs and occasionally figurative elements, a straight or downward tapering shaft with or without flutes, and feet in the form of sculpted feline paws ${ }^{36}$. The tabletop is always rectangular. Numerous examples of this group of marble tables have been found in the atria of Pompeian domūs ${ }^{37}$.

Mensae have been chosen for the following analysis because they hold a special position in the genre of marble tables ${ }^{38}$. Compared to other types, these four-legged examples presented numerous disadvantages from a rational, technical and functional perspective. They were extremely fragile, breakable, expensive and difficult to transport. They remain the most unstable of all known stone tables and statistically have the highest breakage rate. The paws and the narrow shafts of the legs are extremely difficult to carve and had to be secured with additional grouting and struts ${ }^{39}$. Consequently, form and materiality contradict one another to a certain extent. These static problems serve as one argument for the scientific hypothesis that wooden predecessors had to exist ${ }^{40}$.

The existence of this table form can be traced back to the $5^{\text {th }}$ century B.C. when they appear on Attic vase paintings in the context of symposia (Fig. 2a-b) ${ }^{41}$. This Greek furniture, made with timber rather than marble, has the same fluting on the front of the legs, the carved feline feet and round bosses at the top of the supports (Fig. 2b) ${ }^{42}$. These design features are almost identically reproduced on the marble tables from Pompeii - the round, ornamental bosses can be identified on many

34 Hahn 2005, 18; Kalthoff et al. 2016, 26-29.

35 Moss (1989, 44-52. 794-853) defined them as 'Type 10'. This paper focuses on one single, particular type of marble table, with the intention of bringing together shape-related objects. Creating a typology of marble tables by the number of (or decoration applied to) their legs, however, is methodologically inappropriate in terms of reflecting the role of this type of furniture in the ancient household: see Dickmann 1999, 110 n. 320. The development, design and use of mensae cannot be understood by a material-inherent typology, but rather by the transformation of domestic architecture and the integration of these tables into it: see Dickmann 1999, 108-121. 125f. 301-309. 375-378.

36 Moss 1988, 45-47. In rare cases they may also depict the claws of a griffin. Moss (1989, 48) gives six examples, including Moss 1988, cat. nos. 51. 54 from Pompeii.

37 Sixty tables and table fragments of this type are preserved in Pompeii, Herculaneum and in the Museo Archeologico Nazionale di Napoli: see Moss 1988, 799-816. 821-848 cat. nos. D8 - D31. D39 - D74 and Dickmann 1999, 115. Eight mensae are completely preserved and still carrying their tabletops. A list of them can be found in the appendix. 38 Marble tables in general have rarely received scientific attention, despite their richness of form and artistic elaboration. Those from Pompeii were discussed for the first time on a smaller scale by Pernice (1932, 1-12). In the 1980s, Robert Cohon and Frederick Moss created different typologies and chronologies for various kinds of Roman marble tables: see Cohon 1984, 20-151; Moss 1988, 11-54. Here we find types like 'multiple/standing/seated figures', 'protomes on feline feet', 'squared pillars', 'knotty clubs' or 'tables with three/four supports'. These studies and the observations formulated therein on the decor and functional spectrum of this furniture still constitute the current state of research: cf. De Carolis 2007, 110-114; Sinn 2015, 304-306.

39 On these negative criteria, see Moss 1988, $44 \mathrm{f}$.

40 Deonna 1938, f.; von Hesberg 1980, 434; Cohon 1984, 21; Moss 1988, 49 f.

41 Boardman 1990, 122-131; Andrianou 2006, 251-257; 2009, 50-59.

42 See, for example, the bowl of Makron (New York, Metropolitan Museum of Art, inv. 20.246); Murray 1990, Pl. 16 Fig. A. 


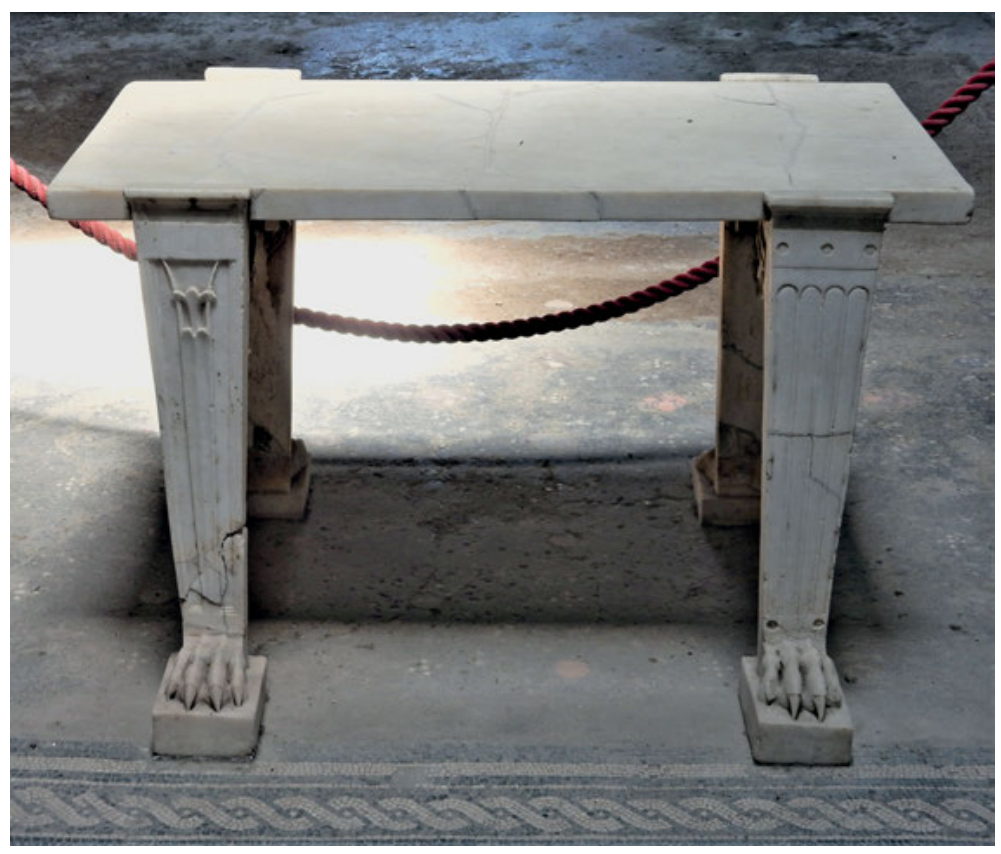

Fig. 1: Pompeii, Casa di Marco Lucrezio Frontone (V 4,a), atrium with mensa.

mensae (Fig. 3) and are interpreted as a visual reflection of the nail heads on wooden tables. Two different and separately discovered mensae table legs from Pompeii support this interpretation ${ }^{43}$. Made of grey and white marble, designed with ornamental flutes and standing on paws, each of these leg fragments is topped with a flat panel with several (two ${ }^{44}$ and three ${ }^{45}$, respectively) small drill holes in it. According to Christopher Moss, these holes are intended to hold light decorative attachments made of bronze, such as bosses. They may thus refer even more clearly to the original materiality of the metal nails. Furthermore, scattered finds of bronze mensae legs (for example in the cargo of the Mahdia shipwreck ${ }^{46}$ ) and bronze fittings for wooden legs provide evidence for the existence of mensae in materials other than marble ${ }^{47}$. One such fitting has even been found in Pompeii ${ }^{48}$.

However, a direct and linear development or connection between the Greek symposion tables, the bronze fragments and the marble tables of the Early Imperial period is not supported by current research. Studies of these pieces of furniture are too fragmentary. Yet the previous considerations show that the formal design of mensae already existed before they became popular in Roman domestic spaces. The material transfer to marble was obviously particularly attractive, in spite of the disadvantages of marble mensae described above ${ }^{49}$.

Usually, the mensae from Pompeii were made from white marble, with coloured stones only rarely used. However, no local marble was employed (from Luni, for example), but rather Pentelic marble from Attica ${ }^{50}$. Regional workshops in Italy were apparently able to obtain materials from the entire Mediterranean area and process them. In Pompeii, one marble workshop in the Casa dello

43 Moss 1988, 826 cat. no. D 45. 836 f. cat. no. D 55.

44 Moss 1988, 826 cat. no. D 45.

45 Moss 1988, 836f. cat. no. D 55.

46 Fuchs 1963, 29.

47 Richter 1966, 350-352; Moss 1988, 50 f.

48 This fragment was found during excavations east of Insula I 4: see Spano 1910, 277 f. Fig. 10.

49 The phenomena of material transfer, trans- and intermateriality are more profoundly addressed in the contributions by Flecker and Engels, this volume.

50 On this, compare all entries in Moss 1988, 799-816. 821-848 cat. nos. D8-D31. D39-D74. 
Fig. 2a-b: Terracotta kylix, ca. 480 B.C.; a: general view; b: detail of the symposion tables; New York, Metropolitan Museum of Art, inv. 20.246.

Fig. 3: Pompeii, Casa di M. Obellius Firmus (IX 14,4), table leg of the mensa (detail).
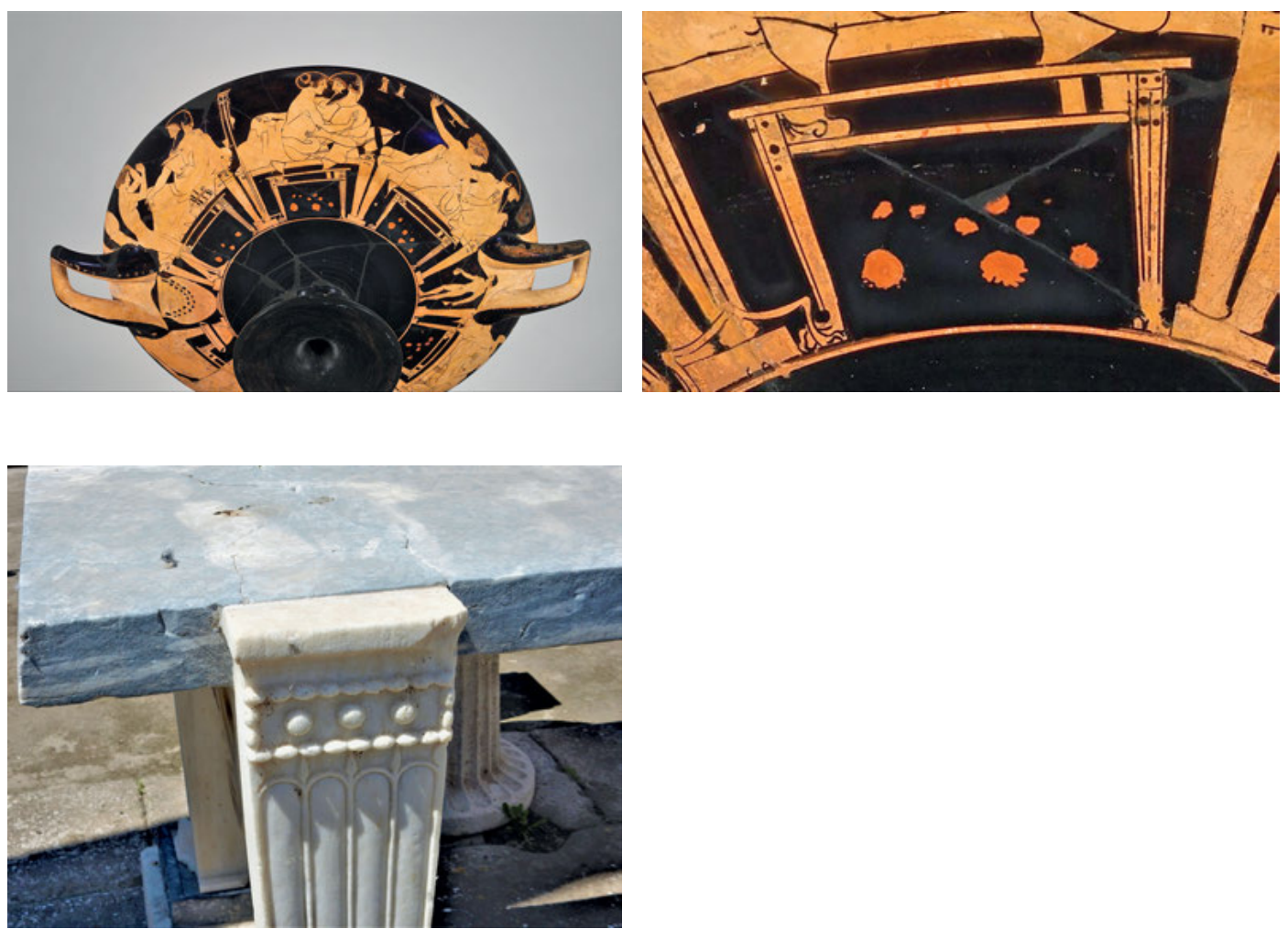

Scultore (VIII 7,24) ${ }^{51}$ is documented. The findings attest to the production of herm tables: five completely preserved examples were found, alongside 15 small herm busts, various shafts, slabs and plaques of marble ${ }^{52}$. Apparently, the workshop imported and acquired a wide selection of pieces and combined them to create a finished product that also used local materials ${ }^{53}$. In the following, the focus will be on the material qualities marble offered, because it can be assumed that the creation of marble mensae:

- fulfilled a functional need in the furnishing of the living space;

- brought certain aesthetic qualities to the interior design;

- could communicate certain meanings to an observer.

\section{Mensae in Pompeian Atria: A Functional, Aesthetic and Semantic Perspective}

During the final years of the Roman Republic, the interior design of the atrium changed. Water fountains and playful arrangements were installed in the centre of this characteristic reception area of the Roman domus. These ensembles included elaborate marble impluvia, fountain figures,

51 In addition to numerous chisels, squares, compasses and a saw still embedded in a block of marble, six trapezophoroi (table legs), five pieces of broken sculpture, two herm shafts, and numerous blocks, cut pieces and slabs of marble were documented: see Fiorelli 1861, 63. 70 f.; Sievers 1938, 36; Mustilli 1950, 215f.; Moss 1988, 239; Eschebach 1993, 392.

52 Earlier research suggested that large-format sculptures were manufactured here: see Romanelli 1811, 204 f.; Mazois 1824, 16; Bonucci 1827, 187; Vinci 1831, 38; D’Aloe 1861, 155; see also Moss 1988, 229.

53 A few pieces of figurative sculpture were found, but unlike the herm tables these were all broken. It has been argued that the sculptures were being stored here while awaiting repair by pinning and gluing (Moss 1988, 232). 


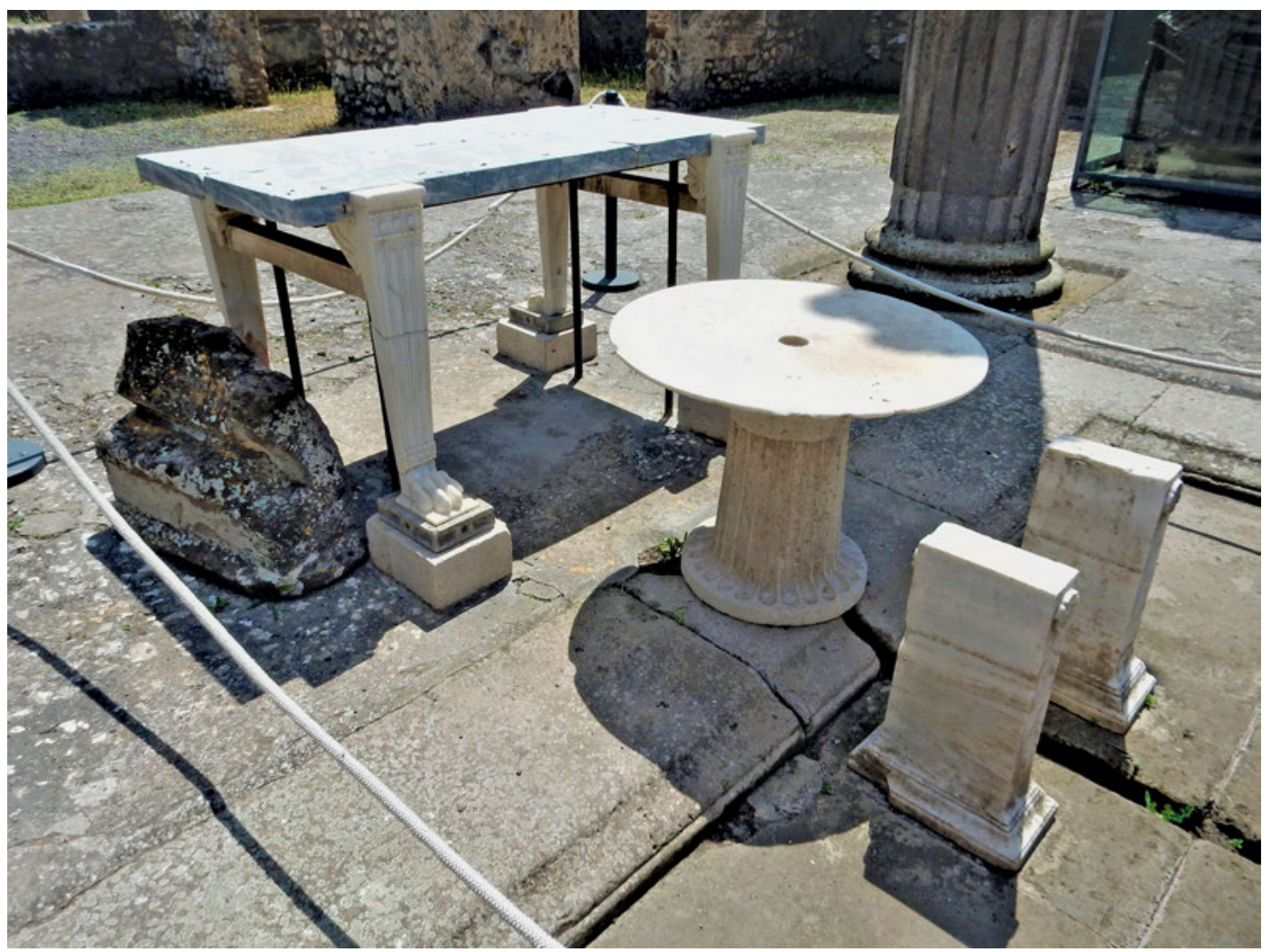

labra and marble tables (Fig. 4) (54 $^{54}$ By the end of the $1^{\text {st }}$ century B.C., these tables no longer stood in front of an atrium wall, but rather directly adjacent to the impluvium ${ }^{55}$. The four-legged mensae appear during this developmental period ${ }^{56}$. Nine of the twelve examples with known findspots in Pompeii were set up immediately next to the impluvium ${ }^{57}$. They were placed along the visual axis of the entrance and (ideally) in the symmetrical centre of the room. Sometimes they stood alone and thus became a visual centrepiece, emphasised by virtue of their positioning, size and physical presence. This practice corresponds remarkably well to descriptions provided by Varro ${ }^{58}$ and seems to have remained popular until the destruction of the city in A.D. $79^{59}$. All in all, these

54 Dickmann 1999, 114 f.; Haug 2020, 484 f. 488-493. This 'filling' of the atrium with furnishings could only occur because the garden area was established as a living area: see Dickmann 1999, 125. The living rooms previously located around the atrium were moved to the peristyle in the posterior part of the house. Concerning this relocation of the living quarters, see Dickmann 1999, 144-151.

55 Dickmann 1999, 114. Solid stone tables - initially mostly made of travertine - had already been an important furnishing element in Pompeian atria since the $2^{\text {nd }}$ and early $1^{\text {st }}$ century B.C. These early examples were intended to stand against a wall because they were carved on only three of their four sides. This is true for monopodia as well as two-legged tables with closed sides: see Pernice 1932, 1-5; Dickmann 1999, 108 f.; Haug 2020, 201.

56 Dickmann 1999, $115 f$.

57 For this list, see Moss 1988, 333f. Eight of these nine examples are mentioned in the appendix (nos. 2-9). One more table from I 4,9 must be added: cf. Moss 1988, $829 \mathrm{f}$. cat. no. D49. This table, made of medium grain, semi-translucent white marble with mica and decorated with vine scrolls and volutes, is stored in the site's magazines (Granai del Foro) today. The ornamental motifs are unique, with the decoration varying from one leg to the other. Thanks to the presence of production marks, this table has been interpreted as an ancient pasticcio. Moss $(1989,828)$ suggests that we can identify different artisans working in one single workshop.

58 Varro Ling. 5, 125.

59 Since the Augustan period, interiors included herms with portraits of the ancestors: see Dickmann 1999, 118-121; Haug 2020, 490-493.
Fig. 4: Pompeii, Casa di M. Obellius Firmus (IX 14,4), arrangement of mensa, labrum and basin base beside the impluvium. 
marble tables were probably the most impressive and most expensive pieces of furniture in Pompeian houses ${ }^{60}$.

A functional perspective: In Roman Pompeii, there was no fixed, canonical interior design, as established in Western European Modernism. Most furniture from Roman households could be used flexibly depending on the situation. Dining couches, stools, side tables, lighting equipment and so on were not bound to one single room but were rather arranged situationally ${ }^{61}$. It is self-evident that, unlike their wood or bronze counterparts, marble tables do not comply with these requirements. They were definitely not easily moved. By using marble for these tables, artisans created something new, something quite heavy and made of a material that is resistant and durable when compared to timber. Because all of these marble tables stand with their feline feet on pedestals or small plinths ${ }^{62}$, they evoke a statuesque impression ${ }^{63}$.

On the basis of literary sources ${ }^{64}$, the most common assignment of function states that these tables served as a representative place to display the precious tableware of the household (aenea $v a s a$ ) in the atrium (ad impluvium) ${ }^{65}$. And indeed, numerous objects and finds matching that description have been documented together with marble tables in Pompeian households ${ }^{66}$. Of course, the location of the objects must be critically examined in each individual case, but the general impression is sufficient evidence to suggest that at least vessels, devices and other objects were probably presented on these tables in the atrium. There is also evidence to suggest that small format bronze statues were displayed on mensae ${ }^{67}$. In these cases, the tables create a special and highly visible place of display by positioning them on an elevated surface within the room; from a practical perspective, then, mensae thus served as large, impressive marble bases for smaller objects of particular value or significance. This spatial setting highlighted the objects, excluding them from the 'everyday' world. The positioning of the marble tables in the atrium, preferably on the central axis with fauces and tablinum, meant that they were prominently staged for every visitor and passer-by (when the front door was open). Their function as magnificent 'display tables' thus becomes absolutely clear. Ironically, the archaeological record suggests that these tables were also used as a place for the pots and pans of everyday life, as well ${ }^{68}$.

Some mensae from Rome and other cities in Latium can be identified as donations made to patrons on the basis of their inscriptions. As 'quasi-public monuments of dignity' ${ }^{69}$, these examples

60 Eck - von Hesberg 2004, 158.

61 Mols 1999, 129f. 146; Dickmann 1999, 108. 281 f.; Deppmeyer 2011, 225. For wooden and bronze tables, see Mols 1999, 37-43; Croom 2010, 68-74. Some bronze tables even had a folding mechanism consisting of collapsible legs and a tabletop: see Klatt 1995, 349-573; Hielscher, forthcoming.

62 Moss 1988, 45.

63 Placing three-dimensional objects on pedestals can be compared with the framing of two-dimensional images. In visual studies (Bildwissenschaften), frames are considered devices that separate an image from its surroundings, making it distinguishable. A frame creates distance, removes the image from the real world surrounding it and assigns it an independent space. On frames in Classical Antiquity, see Platt - Squire 2017; Haug 2015, 10-12. Identifying frames for three-dimensional objects is problematic in so far as object boundaries and image boundaries are usually congruent: see Gombrich 1982, 137. An image-like quality of things can, however, be achieved by using bases and pedestals. The principle of creating the pictoriality through the use of bases was applied in Greek vase painting of the Classical period: see Schefold 1934, 30-75; Oenbrink 1997, 194-197.

64 Varro Ling. 5, 125: Altera vasari mensa erat lapidea quadrata oblonga una columella; vocabatur cartibulum. Haec in aedibus ad compluvium apud multos me puero ponebatur et in ea et circum eam aenea vasa: a geredo cartibulum potest dictum.

65 Pernice 1932, 9; Moss 1988, 281-290; Dickmann 1999, 110; Eck - von Hesberg 2004, 159; Croom 2010, 79-84; Sinn 2015, 304. Although literary sources after Varro (Liv. 39, 6, 7; Plin. HN 34, 14) equate cartibula with monopodia (single support tables), this function can also be assumed for the two- and four-legged stone tables. Eck and von Hesberg $(2004,159)$ remain uncertain as to whether a cartibulum is a concrete table form or a functional designation.

66 Moss 1988, 281-290.

67 Moss 1988, 277-281; Eck - von Hesberg 2004, 162; Haug 2020, 485 f.

68 Caruso 1979, 139; Moss 1988, 240.

69 Dickmann 1999, 118. 
transform the atrium of a domus into a 'public space accessible to the inhabitants of the city"70 and represent an extraordinary declaration of loyalty and materialised form of public honour. At this point, it is difficult to maintain the division between the functional and semantic qualities of marble tables. It is possible that Pompeian mensae also brought a new, politically representative dimension to the furnishing of atria by imitating this practice identified in other cities. However, since no inscribed mensae have been found in Pompeii, this function must remain hypothetical in that location ${ }^{71}$.

Due to the material properties of marble, mensae occupy fixed spots in the house and their spatial setting is invariable. Everyday life and activities must have either moved around them or incorporated them. The tables could be used for display during ceremonies or festivities, such as weddings or births, or could have been actively integrated into such celebrations through practical use $^{72}$. The contexts of numerous marble tables in Pompeii indicate that they were also involved in domestic cult activities, serving as altars in front of niches and household shrines, for example ${ }^{73}$.

An aesthetic perspective: Creating a four-legged table in marble not only affected its mobility, it also gave it a completely unique aesthetic appearance ${ }^{74}$. The visual impression created by mensae was influenced to a great extent by their materiality, but their formal design, ornamentation and spatial setting were also important aesthetic factors. As already described, mensae were highly visible, emphasised and staged as centrepieces in the house. Their general visual impression was quite balanced due to their rectilinear scheme and symmetrical linear form. The preferred frontal view must have been directed towards the tables' long side. Mensae were designed to be symmetrically identical ('spiegelsymmetrisch') and therefore possess a clear axis; their orientation was typically in harmony with the spatial axis of the room, emphasising it ${ }^{75}$. The corner-facing feline paws established directionality, facilitating views from the front, back and sides ${ }^{76}$.

Sunlight shining through the compluvium created a 'spotlight' on the marble tables, so that they would have attracted a great deal of attention. The material aesthetics of the marble could thus be experienced in great and precise detail. There is no evidence that these objects were painted or stuccoed. Their materiality was prominently visible, and thus the impression that they made depended upon the type of marble employed. The Pompeian pieces were made of white, glossy varieties ${ }^{77}$ and depending on the structure of the marble, the table legs could appear opaque and dull, translucent or sometimes even transparent ${ }^{78}$. The four supports of the mensae were extremely slender, and in some cases, they tapered towards the bottom. Together with the fluting, which removed even more material from their form, this permitted light to permeate the material, which makes some examples appear almost glassy. Marble varieties with a high component of mica are characterised by glittering effects under light, sometimes with a golden shimmer. These marbles thus give the tables a fine glimmer or glow, which attracts the eye. Other types of marble have distinctive grains running in different directions, splitting into countless fine linear patterns ${ }^{79}$. The eye follows their individual courses, and their complex mergers and separations (Fig. 5a-b).

70 Dickmann 1999, 118; see also Eck - von Hesberg 2004, 158.

71 Moss 1988, 251 f.; Dickmann 1999, 116f.; Eck - von Hesberg 2004, 143 f.

72 Haug 2020, 118 f. 484.

73 A marble table discovered next to the eponymous fountain in the Casa della Fontana Grande (VI 8,22), has been interpreted as a support for a portable altar, bronze patera, vases and lamps. A comparable set of objects (including figures of the Lares) was found on a marble table in the Casa di Trebio Valente (III 2,1). These and further examples are discussed by Moss (1989, 260-268).

74 For the aesthetic perception of marble in Roman antiquity, see the contributions by Beck and Barker, this volume. 75 Moss 1988, 334; Haug 2020, 493.

76 Wolf 2019, 13.

77 Moss 1988, 797 cat. no. D6. 812-824 cat. nos. D39. D40. 825 cat. no. D43. 826 f. cat. no. D46. $827-840$ cat. nos. D47D61. 842 cat. no. D64. 844-847 cat. nos. D67-D73.

78 On transparency as an aesthetic quality of materials in Pliny's Naturalis historia, see Haug - Hielscher, this volume. 79 Moss 1988, 826-828 cat. nos. D46. D48; Appendix, no. 3. 
Fig. 5a-b: Pompeii, Casa di Poppaeus Sabinus (IX 5,11), atrium with mensa; a: general view; b: detail of pavonazetto table legs.
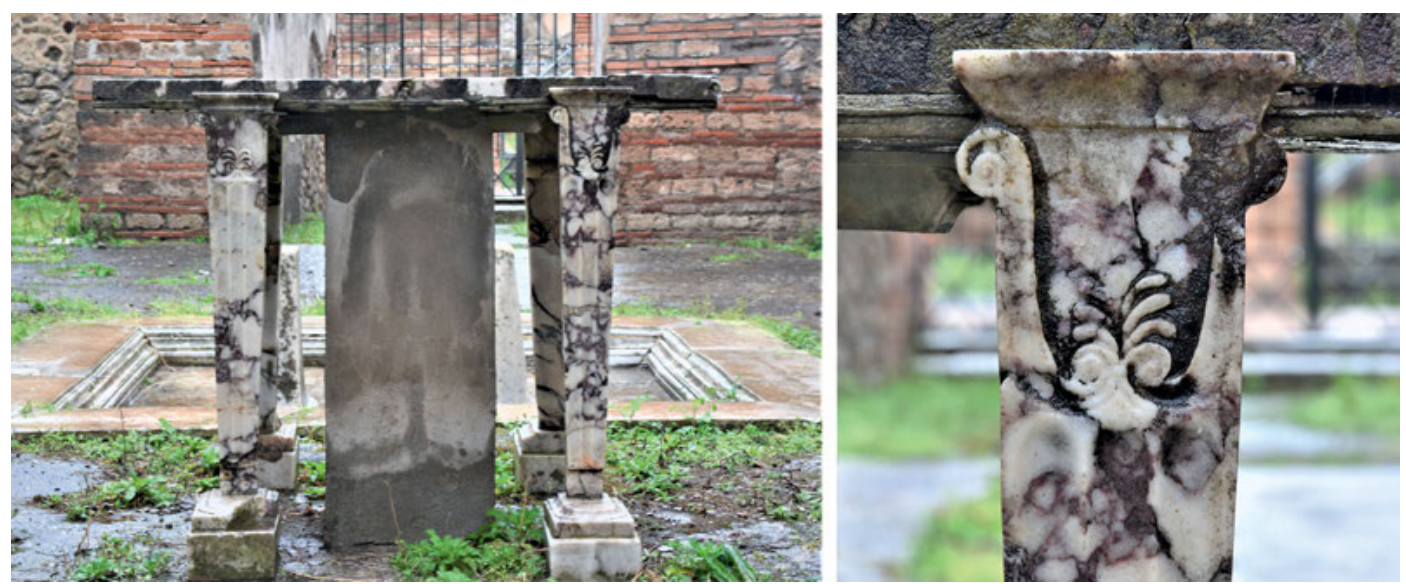

Only two of the eight tables with preserved tabletops were produced from a single material ${ }^{80}$. In all the other examples, different types of marbles were combined. The table in the Casa del Fabbro (I $10,7)$, for example, was made from two different types of white marble ${ }^{81}$. The legs and tabletop do not differ in colour, but rather in their crystalline structure and translucence. It is notable that the more translucent marble was used for the slender legs, presumably to emphasise the fragility of the construction. Another unique material combination can be found in the Casa degli Scienzati (VI $14,43)$. In this case, the legs were produced from pinkish portasanta and combined with a tabletop of white Breccia di Settebasi ${ }^{82}$ (Fig. 6). Here a bi-chromatic and visually conspicuous distinction between the legs and the tabletop becomes apparent. By contrasting with each other via their materiality, these individual parts of the table come into visual competition, vying for the beholders' attention. Further, the pigmentation of the coloured marble gains significance through this contrast with the white. This decorative phenomenon is not an isolated case, however. In three further examples, white marble table legs were combined with bardiglio, a fine-grained grey marble with white mottling ${ }^{83}$ (Fig. 7). Here again, the aesthetic effects of dichroism and contrast become apparent. Unfortunately, we do not know whether there were inverse examples of this colour combination, in which table legs produced in grey marble were combined with white tabletops ${ }^{84}$.

In summary, these marble tables are clearly an aesthetically pleasing furnishing element. The visual qualities of the marble are used in a variety of ways to highlight these pieces. The colour, shine and translucence of the white and coloured marble were not simply composed in an unthinking way but were rather combined with the intention to produce specific aesthetic effects.

A semantic perspective: With regard to the meaning of marble tables, three sets of semantic oppositions will be addressed: placement in public versus private space, the use of imported versus regional materials and the creation of luxurious versus 'standard' types. Impressive tables made of marble or other stones find their origin in public space. They most commonly are found in sanctuaries, where they have been identified as votive offerings, monuments of honour or sacrificial tables ${ }^{85}$. In public space, especially two-legged tables that were quite similar in design to

80 Appendix, nos. 4. 8.

81 Appendix, no. 5.

82 Appendix, no. 9.

83 Appendix, nos. 1. 7. 8; Moss 1988, 823-826 cat. nos. D41. D42. D44. D45. 842 f. cat. no. D65. 847 cat. no. D73.

84 Moss 1988, 823-826 cat. nos. D41. D42. D44. D45. 842f. cat. no. D65. 847 cat. no. D73.

85 Deonna 1938, 24-29; Moss 1988, 241-244; Dickmann 1999, 109; Eck - von Hesberg 2004, 163-166. Further examples of public stone tables are the mensae ponderariae from Tivoli and Pompeii (Eck - von Hesberg 2004, 144), as well as prize tables ('Preistische') in gymnasia (Eck - von Hesberg 2004, 162f.). Two-legged marble tables were erected as funerary monuments from the Early Imperial period: see von Hesberg 1980, 433 f. It is assumed that the function of 


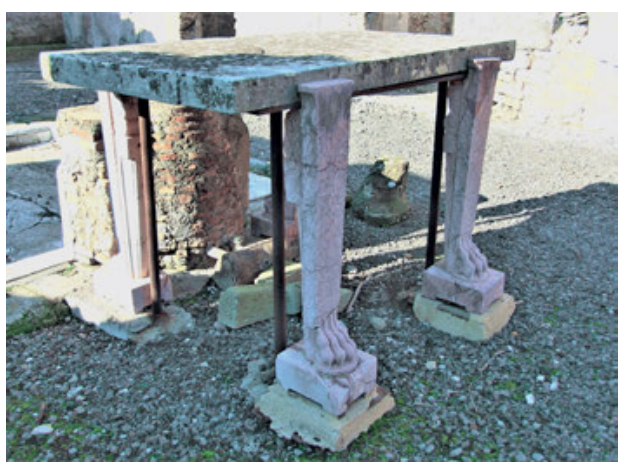

Fig. 6: Pompeii, Casa degli Scienziati (VI 14,43), atrium with mensa.

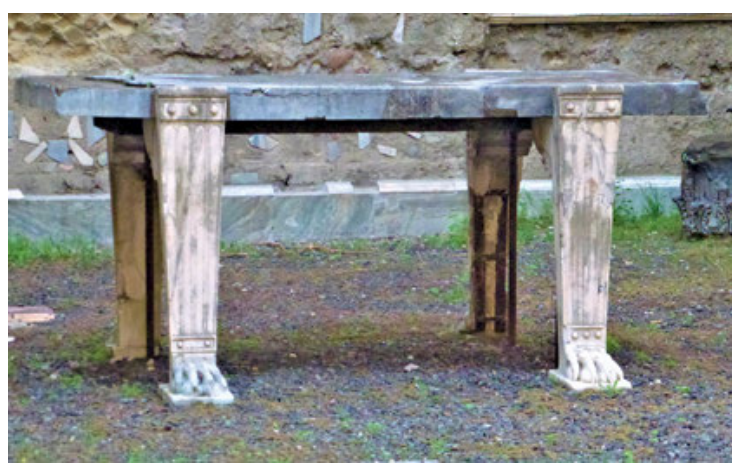

Fig. 7: Herculaneum, Palaestra (Ins. Or. II 4), western apsidal room with mensa.

four-legged mensae (although closed on the sides) appeared ${ }^{86}$. A handful of such examples from public spaces have been preserved in the Vesuvian area, including tables from the Area Sacra Suburbana of Herculaneum and the Sanctuary of Isis in Pompeii, which likely served as offering tables or were used for other cultic activities ${ }^{87}$. Furthermore, stone tables were erected in funerary contexts as grave markers ${ }^{88}$, while the largest mens $a$ from the Aula Absidata in Herculaneum was supposedly a base for the statue of an emperor (Fig. 7) ${ }^{89}$.

In domestic space, mensae would have been eye-catching pieces of furniture with functions that were flexible and situational ${ }^{90}$, but their characteristic form and materiality created a specific impression or atmosphere in public spaces. White marble, which was used to build the majority of Pompeian mensae, was also employed to construct large public buildings, squares and temples, and thus it was associated with a kind of urban or public atmosphere. If we transfer this materiality to a domestic context, perhaps objects such as mensae seemed to be elements of architecture more than mobile furniture. Their central position in the atrium, in combination with their marble composition, gave these tables a more public/representative character ${ }^{91}$.

In general, marble tables could be fabricated from up to seven different types of marble ${ }^{92}$, which originated from throughout the entire Mediterranean area. In addition to numerous white marbles, every coloured marble known in Roman architecture (over 20 separate varieties) was used to build mensae ${ }^{93}$. Unique varieties of coloured marbles were located topographically and labelled according to their region of origin ${ }^{94}$, e.g., marmo numidicum or marmor phrygium ${ }^{95}$. Imported stones could thus be classified as 'foreign' or 'native', and naturally the former had the charm and

the table corresponds to that of an altar (von Hesberg 1980, 438). Marble tables were also used as bases for equestrian statues during the Early Imperial period.

86 Eck - von Hesberg 2004, 146-158.

87 Moss 1988, $244 \mathrm{f}$.

88 Moss 1988, 253-260.

89 Suggested by Maiuri 1958, 182; Moss 1988, 244. This concrete definition of function needs to be proven in detail. For further public contexts, see Moss 1988, 250-252.

90 Dickmann 1999, 109; Eck - von Hesberg 2004, 166.

91 Dickmann 1999, 118.

92 Moss 1988, 55 cat. no. A 219.

93 See Moss (1989, 66-82) for an alphabetical list of the different types, their origins and exact use. White, coloured, regional and imported marble types were often combined in a single piece.

94 On the symbolism of different stones, see Raff 2008, 39-31. This symbolism changed over the course of time: various sources show that during the Imperial period, porphyry was associated mainly with Ptolemaic Egypt, whereas in Byzantine times this material was mainly understood as a reference to Rome; see Raff 2008, 15.

95 See also the contributions by Beck and Barker, this volume. 
attraction of the exotic ${ }^{96}$. Furthermore, the economic value of a marble was linked to the costs of quarrying and transporting it from its point of origin ${ }^{97}$, something that Pliny strongly criticises in connection with the use of marble in domestic architecture ${ }^{98}$. Consequently, the materiality of mensae could symbolise the costs associated with their production, communicating the wealth and prosperity of their owners ${ }^{99}$. From this perspective, these tables did not need precious aenea $v a s a$, statuettes or tributes from devotees placed upon them in order to appear representative. Their special materiality meant that they themselves were a symbol of the influence and prestige of the dominus. But let us have a closer look at the mensae of Pompeii.

Deducing semantic interpretations from the varieties of marble employed in Pompeian mensae is methodologically delicate. Moss' observations provide us with the basic evidence to determine stone types and their origins. To confirm or (where appropriate) clarify Moss' marble identifications, a comprehensive re-evaluation of the marble tables from Pompeii would be necessary, but we can at least make some brief remarks here.

First of all, it is striking that Pentelic marble from Attica was favoured over white marble from Luni. This is particularly remarkable because most of the tables were produced after the quarries at Luni had been opened, meaning that a cheaper high-quality material was already available in Italy ${ }^{100}$. Together with other marble objects ${ }^{101}$, tables are generally considered to be imported luxurious furnishings ${ }^{102}$. Their forms, decoration and especially choice of material are generally defined as the work of the 'neo-Attic' ${ }^{103}$ workshops. Influenced by discoveries such as the Mahdia shipwreck, marble tables have generally been included in a group of furnishings thought to have been imported from the East ${ }^{104}$.

But many marble tables do not fit into this common interpretation ${ }^{105}$, including the mensae from Pompeii. Among these we find numerous crossovers between different types of marble, some of which were imported, some of which had an Italian origin. A small group of mensae in Pompeii ${ }^{106}$, Herculaneum ${ }^{107}$ and the Museo Archeologico Nazionale di Napoli (MANN) ${ }^{108}$ share similar forms, proportions and ornaments: their legs, which are produced in Pentelic marble, are fluted and topped with panels depicting bosses; they stand universally atop sculpted paws ${ }^{109}$. Identical legs

96 Raff 2008, 74. 79 f.

97 Eck - von Hesberg 2004, 159; Raff 2008, 46-49; Sinn 2015, 302.

98 Plin. HN 36, 2; Sinn 2015, 302-304. Vitruvius (De arch. 1, 2, 8) suggests using locally available materials for the construction of buildings in order to save money.

99 Dickmann 1999, 118; Hölscher 2017, 32.

100 On this observation, see Moss 1988, 56-59.

101 Tables are only one of many object categories that appear in marble over the course of the late $2^{\text {nd }}$ and $1^{\text {st }}$ centuries B.C.; others include candelabra (Cain 1985; Cain - Dräger 1994), putealia (Golda 1997) and craters (Grassinger 1991), for example.

102 Eck - von Hesberg 2004, 159; Sinn 2015, 302. On the marble furnishing elements from Pompeii that are now in the MANN, see Carrella (et al. 2008) with a list of further literature.

103 This term describes the notion that the increasing demand of the Roman consumer classes for furnishings of 'Greek' style during the $2^{\text {nd }}$ century B.C. was initially regulated by imports but could no longer be met over time. This led to a migration of craftsmen and workshops - and with them a migration of stylistic forms - from the 'Hellenistic' east to the 'Roman' west. The imported products influenced local decorative forms, which led to adaptation; these forms were then produced on the Italian peninsula. The research on the phenomenon of Neo-atticism is too extensive to be listed here in its entirety (see, among others, Börker 1973, 283-317; von Hesberg 1981, 201-245; Cain - Dräger 1994a, 809-830; Cain 1995, 893-896). Today, however, the simple linearity of this process is being questioned: see Maschek 2008, 185-217; Wallace-Hadrill 2008, 315-434; Reinhardt 2018a, 299-325.

104 Moss 1988, 196f. For the rise of marble in Late Republican and Early Imperial architecture, see the contributions by Beck and Barker, this volume.

105 See Moss 1988, 193-206.

106 Appendix, no. 7; Moss 1988, 836 cat. no. D54. 846 cat. no. D71.

107 Moss 1988, 797 f. cat. no. D6.

108 Moss 1988, 813-815 cat. nos. D21. D25. D28.

109 Moss 1988, 203. 
have been found in $\operatorname{Kos}^{110}$, Delos ${ }^{111}$ and Delphi ${ }^{112}$, and thus it is unlikely that they are of Italian provenance. Yet the preserved tabletops from the corresponding mensae in Pompeii are made of Italian marble. It seems obvious, then, that the legs were imported to Campania and then combined with tabletops made from regional material ${ }^{113}$.

Consequently, there is less reason to interpret these mensae a priori as 'exotic' luxury imports on the basis of their materiality ${ }^{114}$. Rather, they appear to be innovative creations that utilised materials and forms drawn from a wide range of available and accessible design ideas ${ }^{115}$.

\section{Summary: The Interconnectedness of Materiality and Object Properties (Function, Aesthetics, Semantics)}

A distinction between the function, aesthetics and semantics of materials and object properties is methodologically necessary. Only by distinguishing these different qualities can we systematise our perspectives on material objects, the 'things' of the world. However, this relates to the theoretical and methodological realm, rather than to the de facto perception of materials and things. In the real world, function, aesthetics and semantics are connected in objects and when they are perceived, these categories create a network of relationships and can thus begin to blur together. Accordingly, it is necessary to think about materiality in very specific situations and perceptual contexts, as well as from concrete perspectives.

Marble tables are a good example of this approach. Marble was neither arbitrarily nor pragmatically employed for the construction of mensae in Pompeian houses. Marble tables were not mobile. In this respect, they were clearly distinguishable from the other furniture in the household. Consequently, they could not have served as dining and side tables, but were rather static furnishings, much like sculpture and or architectural elements. The plinth upon which the tables were set and the visuality of the marbles enhanced this impression. Their 'solidification' and 'petrification' allowed four-legged tables to become statuary elements of representation, 'staged' in terms of their aesthetic and semantic effects. Carving a four-legged table out of marble was a technical challenge, because the material and form were not compatible, since these tables were originally produced from timber. At the same time, mensae derived their decorative charm from the use of marble. The slender legs, for example, looked more spectacular when made from a translucent marble, although this choice of material also emphasised their static fragility. The various combinations of different stones - some local, some imported (and thus exotic) - left no doubt that the choice of materials was an intentional decision integral to the tables' designs. The combination of the characteristic shape and the use of marble in the production of mensae gave rise to a 'product language' that was specific to these tables. For the observer, this language opened up various semantic interpretations and potential associations: for example, the indication of a 'public' space, or the display of the owner's economic power. The different types of stone were consciously combined, staged and displayed. This was intended to achieve certain functional changes, aesthetic effects

110 Mendel 1914, 37 f.; Moss 1988, 203.

111 Deonna 1938, 23f.; Moss 1988, 203.

112 Moss 1988, 203.

113 On the downside, complete marble tables were rarely imported (Moss 1988, 206).

114 The importance of Greek workshops in the production of marble tables is probably overestimated, with Italian workshops of much greater import: see Moss 1988, 206; Maschek 2008, 186. Stonemasonry workshops extended across the Italian peninsula and are documented especially near quarries: see Moss 1988, 224-229.

115 Haug (2020, $11 \mathrm{f}$.) introduces therefore the concept of 'Decoscapes'. Wallace-Hadrill (2008) describes this phenomenon as a part of Rome's cultural and consumer revolutions. In this reading, Roman craftsmen and workshops acquired forms, materials and products from abroad and transformed them into something new, independent and original (Wallace-Hadrill 2008, 360 f). 
and symbolic statements. But to reduce a marble table to only one of these characteristics would be far too simplistic.

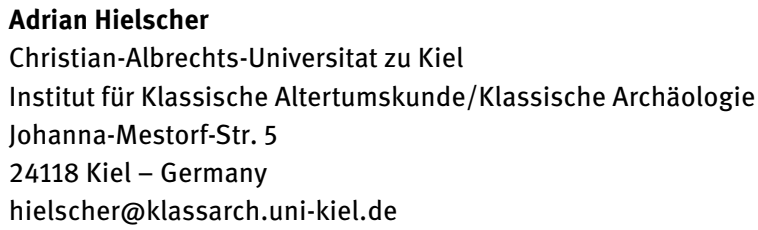

\section{Appendix: List of Four-Legged Marble Tables (mensae) from Pompeii and Herculaneum}

The mensae from Pompeii and Herculaneum that are particularly relevant to this paper are listed below. These pieces were selected because their precise findspots are documented, they are visible in situ today and their tabletops are preserved as well. The information collected here is based on the catalogue produced by Moss (1989).

1. Herculaneum (Aula Absidata) (Fig. 7)

Reference: Moss 1988, 797 cat. no. D6.

Leg material: Pentelic marble (fine-grained, fairly translucent white marble with golden tinges and mica streaks). Leg decoration: The fronts of the shafts are fluted with four round reeds; at top and bottom of each shaft is a framed panel with three round bosses and an astragal frame; legs end in paws.

Tabletop material: Bardiglio nero.

Date: Julio-Claudian/Flavian.

Comments: This decoration appears with slight variations in many domestic contexts in Pompeii (Moss 1988, cat. nos. D50-D53).

Bibliography: Maiuri 1958, 122-126; von Hesberg 1980, 425; de Vos 1982, 283.

\section{Pompeii (VII 12,28, Casa del Balcone Pensile)}

Reference: Moss 1988, 822f. cat. no. D40.

Leg material: Medium/fine-grained, translucent, white marble with prominent crystal structure.

Leg decoration: Tops of the legs decorated with bead and reel moulding; on the capitals of the legs comic masks, bucrania and garlands are carved in relief; sides of the bracket adorned with a scroll motif with palmettes.

Tabletop material: No tabletop preserved.

Date: Julio-Claudian/Flavian.

Comments: Only legs in Italy decorated with comic masks.

Bibliography: Fiorelli 1875, 292; Engelmann 1898, 59; Döhl - Zanker 1984, 202 f.

3. Pompeii (IX 5,11, Casa di Poppaeus Sabinus) (Fig. 5)

Reference: Moss 1988, 827 f. cat. no. D47.

Leg material: Pavonazetto (medium-grained, semi-translucent creamy white marble with delicate purple and black veins).

Leg decoration: Each shaft is crowned by a cavetto moulding; two volutes on the capital rise to the top of the support; area between the volutes is filled by a palmette; only one paw has survived.

Tabletop material: Breccia di Settebasi (brecciated stone with white clasts of various sizes in a purplish-black matrix). Date: Mid-Julio-Claudian to A.D. 79.

Comments: Tabletop has been reassembled on a modern plate.

Bibliography: Fiorelli 1877, 247; Mau 1879, 194; Grant 1975, 56 f.

4. Pompeii (V 4,a, Casa di M. Lucretius Fronto) (Fig. 1)

Reference: Moss 1988, 830-832 cat. no. D50.

Leg material: Medium/large-grained, translucent white marble.

Leg decoration: Fluted and reeded legs with different ornament motifs.

Tabletop material: Medium/large-grained, translucent white marble.

Date: Julio-Claudian/Early Flavian. 
Comments: This combination of disparate elements has no parallels elsewhere in Italy. Two supports $(A+B)$ came from the same workshop but have different ornamentation. The other two legs $(C+D)$ were recycled from a previous table. All four legs are carved from precisely the same quality of marble and are similar in their proportions, fittings and bases. In general, they are carved and finished in similar fashion. The four legs must represent the products of a single shop, patched together (in a final phase?) into a single table.

Bibliography: Sogliano 1900, 203-205.

\section{Pompeii (I 10,7, Casa del Fabbro)}

Reference: Moss 1988, 832-834 cat. no. D51.

Leg material: Very fine-grained, fairly translucent white marble.

Leg decoration: Fluted legs crowned with a cyma recta moulding; lower portion of the capital presents a frame around three bosses.

Tabletop material: Fine-grained, opaque white marble.

Date: Mid-1 $1^{\text {st }}$ century B.C. to Julio-Claudian period.

Comments: Common model of decoration (see also Moss 1988, cat. nos. D47.D50. D52. D56).

Bibliography: Della Corte 1933, 308; Elia 1934, 279; Allison 2006, 161.

6. Pompeii (IX 14,4, Casa di Obellio Firmo) (Fig. 3-4)

Reference: Moss 1988, 834 f. cat. no. D52.

Leg material: Pentelic (fine-grained, semi-translucent white foliated marble with mica streaks).

Leg decoration: Four round-headed reeds with fillets decorate the shaft; at top and bottom a beaded frame around three bosses.

Tabletop material: Bardiglio (Fine-grained, opaque grey and white marble).

Date: Julio-Claudian.

Comments: Similar models of decoration have been found on Delos (Deonna 1938, $23 \mathrm{f}$.).

Bibliography: Sogliano 1905, 250; Spinazzola 1953, 337; de Vos 1982, 207.

\section{Pompeii (I 7,11, Casa dell'Efebo)}

Reference: Moss 1988, 835f. cat. no. D53.

Leg material: Pentelic (fine-grained, semi-translucent white marble with mica streaks).

Leg decoration: Top of each shaft is crowned with a cyma recta moulding and a frame with three bosses; four reeds run down the shaft.

Tabletop material: Bardiglio (Fine-grained, opaque grey and white marble).

Date: Mid-1 ${ }^{\text {st }}$ century B.C. to Julio-Claudian.

Comments: Similar models of decoration have been found on Delos (Deonna 1938, 23f.).

Bibliography: Maiuri 1927, 40; Caruso 1979, 1318.

\section{Pompeii (VI 7,19, Casa d'Inaco ed Io)}

Reference: Moss 1988, 837 f. cat. no. D56.

Leg material: Fine-grained, opaque white marble with some grey mottling.

Leg decoration: Undecorated tops; body has three reeds; paws were carved separately.

Tabletop material: Fine-grained, opaque white marble with some grey mottling.

Date: Julio-Claudian.

Comments: Shares two extraordinary features with appendix entry no. 5: the unusual fitting of the bracket and the addition of rubblework masonry between two opposed legs.

Bibliography: Fiorelli 1875, 113; Fadda 1975, 1679.

\section{Pompeii (VI 14,43, Casa degli Scienzati) (Fig. 6)}

Reference: Moss 1988, 840 f. cat. no. D62.

Leg material: Portasanta (?) (fine-grained, opaque pinkish-buff stone with fine brecciation).

Leg decoration: Without decoration on the front, volutes on the sides of the brackets.

Tabletop material: Breccia di Settebasi (brecciated stone with thin, light-coloured clasts in a dark matrix).

Date: Mid-Julio-Claudian/Early Flavian.

Comments: Another piece of this table is probably stored in the Granai del Foro magazines (Moss 1988, 841f. cat. no. D63).

Bibliography: Avellino 1846, 90; Breton 1855, 287. 379-381; Fiorelli 1875, 430; Nissen 1877, 21. 419 f. 


\section{Illustration Credits}

Fig. 1: Photo courtesy of Buzz Ferebee. ()Jackie and Bob Dunn www.pompeiiinpictures.com. Su concessione del Ministero per i Beni e le Attività Culturale e per il Turismo - Parco Archeologico di Pompei.

Fig. 2: New York, Metropolitan Museum of Art, inv. 20.246; Public Domain Dedication (CC0 1.0 Universal [CC0 1.0]).

Fig. 3: Photo courtesy of Buzz Ferebee. ( Jackie and Bob Dunn www.pompeiiinpictures.com. Su concessione del Ministero per I Beni e le Attività Culturale e per il Turismo - Parco Archeologico di Pompei.

Fig. 4: Photo courtesy of Buzz Ferebee. (J)ackie and Bob Dunn www.pompeiiinpictures.com. Su concessione del Ministero per I Beni e le Attività Culturale e per il Turismo - Parco Archeologico di Pompei.

Fig. 5: C. Beck, su concessione del Ministero per I Beni e le Attività Culturale e per il Turismo - Parco Archeologico di Pompei.

Fig. 6: Photo courtesy of Buzz Ferebee. ( ) Jackie and Bob Dunn www.pompeiiinpictures.com. Su concessione del Ministero per I Beni e le Attività Culturale e per il Turismo - Parco Archeologico di Pompei.

Fig. 7: Photo courtesy of Buzz Ferebee. (C)ackie and Bob Dunn www.pompeiiinpictures.com. Su concessione del Ministero per I Beni e le Attività Culturale e per il Turismo - Parco Archeologico di Pompei.

\section{Bibliography}

\section{Primary Sources}

Liv.

Livy: History of Rome, Volume XI, Books 38-40, ed. and transl. by J. C. Yardley (Cambridge, MA 2018)

Plin. HN 34 Pliny: Natural History, Volume IX, Books 33-35, transl. by H. Rackham (Cambridge, MA 1952)

Plin. HN 36 Pliny: Natural History, Volume X, Books 36-37, transl. by D. E. Eichholz (Cambridge, MA 1962)

Varro Ling. Varro: On the Latin Language, Volume I, Books 5-7, transl. by R. G. Kent (Cambridge, MA 1938)

Vitr. De arch. Vitruvius: On Architecture, Volume I, Books 1-5, transl. by F. Granger (Cambridge, MA 1931)

\section{Secondary Sources}

Allison 2006: P. M. Allison, The Insula of the Menander at Pompeii III. The Finds. A Contextual Study (Oxford 2006)

Andrianou 2006: D. Andrianou, Chairs, Beds, and Tables. Evidence for Furnished Interiors in Hellenistic Greece, Hesperia 75, 2006, 219-266

Andrianou 2009: D. Andrianou, The Furniture and Furnishings of Ancient Greek Houses and Tombs (Cambridge 2009)

Avellino 1846: F. Avellino, Notizia degli scavi di Pompei di novembre e dicembre 1845 e de'primi mesi del 1846,

Bullettino archeologico Napolitano 4, 1846, 89-96

Beer 2018: R. Beer, Die Ästhetik des Subjektes (Munich 2018)

Bielfeldt 2014: R. Bielfeldt, The Lure and Lore of Light. Roman Lamps in the Harvard Art Museums, in: S. Ebbinghaus (ed.), Ancient Bronzes Through a Modern Lens (New Haven, CT 2014) 171-191

Boardman 1990: J. Boardman, Symposion Furniture, in: O. Murray (ed.), Sympotica. A Symposium on the Symposion (Oxford 1990) 122-131

Bonucci 1827: C. Bonucci, Pompéi décrite (Naples 1827)

Böhme 1995: G. Böhme, Atmosphäre. Essays zur neuen Ästhetik (Berlin 1995)

Böhme 2016: H. Böhme, Agency, Performativität und Magie der Dinge, in: J. Dörrenbacher - K. Plüm (eds.), Beseelte Dinge. Design aus Perspektive des Animismus (Bielefeld 2016) 25-50

Börker 1973: C. Börker, Neuattisches und Pergamenisches an den Ara Pacis-Ranken, Jdl 88, 1973, 283-317

Borg 2015: B. E. Borg, Introduction, in: B. E. Borg (ed.), A Companion to Roman Art (Chichester 2015) 1-8

Bosch 2014: A. Bosch, Identität und Dinge, in: S. Samida - M. Eggert - H. P. Hahn (eds.), Handbuch Materielle Kultur (Stuttgart 2014) 79-76

Brandstätter 2012: U. Brandstätter, Ästhetische Erfahrung, in: H. Bockhorst - V. I. Reinwand - W. Zacharias (eds.), Handbuch Kulturelle Bildung (Munich 2012) 174-180

Bravi 2014: A. Bravi, Griechische Kunstwerke im politischen Leben Roms und Konstantinopels (Berlin 2014)

Breton 1855: E. Breton, Pompeia décrite et dessinée (Paris 1855)

Bürdek 2015: G. Bürdek, Design. Geschichte, Theorie und Praxis der Produktgestaltung (Basel 2015)

Burmeister 2009: S. Burmeister, „Codierungen/Decodierungen“. Semiotik und die archäologische Untersuchung von Statussymbolen und Prestigegütern, in: B. Hildebrandt - C. Veit (eds.), Der Wert der Dinge. Güter im Prestigediskurs (Munich 2009) 73-102 
Cain 1985: H.-U. Cain, Römische Marmorkandelaber (Mainz 1985)

Cain - Dräger 1994: H.-U. Cain - O. Dräger, Die Marmorkandelaber, in: G. Hellenkemper Salies (ed.), Das Wrack. Der antike Schiffsfund von Mahdia I. Exhibition Catalogue Bonn (Cologne 1994) 239-357

Cain - Dräger 1994a: H.-U. Cain - O. Dräger, Die sogenannten neuattischen Werkstätten, in: G. Hellenkemper Salies (ed.), Das Wrack. Der antike Schiffsfund Mahdia II. Exhibition Catalogue Bonn (Cologne 1994) 809-830

Carrella et al. 2008: A. Carrella - L. A. D’Acunto - N. Inserra - C. Serpe (eds.), Marmora Pompeiana nel Museo Archeologico Nazionale di Napoli. Gli arredi scultorei delle case pompeiane (Rome 2008)

Caruso 1979: I. Caruso, Una classe di trapezofori pompeiani. Problemi di produzione locale e esegesi dei motivi ornamentali, RStLig 45, 1979, 129-140

Cohon 1984: R. H. Cohon, Greek and Roman Stone Table Supports with Decorative Reliefs (Ph.D. diss. New York University 1984)

Croom 2010: T. Croom, Roman Furniture (Stroud 2010)

D’Aloe 1861: S. D’Aloe, Les ruines de Pompéi jusqu'en 1861 (Naples 1861)

Debray 2007: R. Debray, Jenseits der Bilder. Eine Geschichte der Bildbetrachtung im Abendland (Berlin 2007)

De Carolis 2007: E. De Carolis, Il mobile a Pompei ed Ercolano. Letti, tavoli, sedie e armadi. Contributo alla tipologia dei mobili della prima età imperiale (Rome 2007)

Della Corte 1933: M. della Corte, Pompei. Inscrizioni dell'isola X della Regione I, NSc 11, 1933, 277-331

Deonna 1938: W. Deonna, Le mobilier délien (Paris 1938)

Deppmeyer 2011: K. Deppmeyer, Innenarchitektur und Möblierung eines römischen Hauses, in: H. Meller - J.-A. Dickmann (eds.), Pompeji - Nola - Herculaneum. Katastrophen am Vesuv (Munich 2011) 225-236

Dickmann 1999: J.-A. Dickmann, Domus frequentata. Anspruchsvolles Wohnen im pompejanischen Stadthaus, Studien zur antiken Stadt 4 (Munich 1999)

Dietrich - Squire 2018: N. Dietrich - M. Squire (eds.), Ornament and Figure in Graeco-Roman Art. Rethinking Visual Ontologies in Classical Antiquity (Berlin 2018)

Döhl - Zanker 1984: H. Döhl - P. Zanker, La scultura, in: F. Zevi (ed.), Pompei 79. Raccolta di studi per il decimonono centenario dell'eruzione vesuviana (Naples 1984) 177-210

Eck - von Hesberg 2004: W. Eck - H. von Hesberg, Tische als Statuenträger. Mit einem epigraphischen Kataloganhang, RM 111, 2004, 143-192

Elia 1934: O. Elia, Pompei. Relazione sullo scavo dell'Insula X della Regio I, NSc 12, 1934, 264-344

Engelmann 1898: R. Engelmann, Pompeji (Leipzig 1898)

Erlhoff - Marshall 2008: M. Erlhoff - T. Marshall, Wörterbuch Design. Begriffliche Perspektiven des Design (Basel 2008)

Eschebach 1993: W. Eschebach, Gebäudeverzeichnis und Stadtplan der antiken Stadt Pompeji (Cologne 1993)

Fadda 1975: N. Fadda, Gli impluvi modanati delle case in Pompei, in: B. Andreae - H. Kyrieleis (eds.), Neue Forschungen in Pompeji und den anderen vom Vesuvausbruch 79 n. Chr. verschütteten Städten (Recklinghausen 1975) 161-166

Fiorelli 1861: G. Fiorelli, Pompeianorum antiquarium historia II (Naples 1861)

Fiorelli 1875: G. Fiorelli, Descrizione di Pompei (Naples 1875)

Fiorelli 1877: G. Fiorelli, Pompeii, NSc 1877, 17-18. 62-63. 247-251

Fox et al. 2015: R. Fox - D. Panagiotopoulos - C. Tsouparopoulou, Affordanz/Affordance, in: T. Meier - M. Ott - R. Sauer (eds.), Materiale Textkulturen. Konzepte - Materialien - Praktiken (Berlin 2015) 63-70

Fuchs 1963: W. Fuchs, Der Schiffsfund von Mahdia (Tübingen 1963)

Fuchs 2015: M. Fuchs, Ästhetische Erfahrungen - Hinweise für den Umgang mit einem komplexen Begriff, in: Kulturelle Bildung online, <https://www.kubi-online.de/artikel/aesthetische-erfahrungen-hinweise-denumgang-einem-komplexen-begriff> (04.01.2020)

Gibson 1966: J. J. Gibson, The Senses Considered as Perceptual Systems (Boston 1966)

Golda 1997: T. M. Golda, Puteale und verwandte Monumente (Mainz 1997)

Gombrich 1982: E. H. Gombrich, Ornament und Kunst. Schmuckbetrieb und Ordnungssinn in der Psychologie des decorativen Schaffens (Stuttgart 1982)

Grant 1975: M. Grant, Exotic Art in Pompeii (New York 1975)

Grassinger 1991: D. Grassinger, Römische Marmorkratere (Mainz 1991)

Grüner 2009: A. Grüner, Ästhetischer Wert und ethisches Urteil. Das Prestigeobjekt der Piscina im Kontext der römischen Luxuskritik, in: B. Hildebrandt - C. Veit (eds.), Der Wert der Dinge. Güter im Prestigediskurs (Munich 2009) 335-369

Grüner 2011: A. Grüner, Vom Sinn zur Sinnlichkeit. Probleme und Perspektiven des Ornamentbegriffs in der antiken Architektur, in: J. Lipps - D. Maschek (eds.), Antike Bauornamentik. Möglichkeiten und Grenzen ihrer Erforschung (Munich 2011) 25-51

Gumbrecht 2003: H.-U. Gumbrecht, Epiphanien, in: J. Küpper - C. Menke (eds.), Dimensionen ästhetischer Erfahrung (Frankfurt a. M. 2003) 203-222 
Hahn 2003: H. P. Hahn, Dinge als Zeichen. Eine unscharfe Beziehung, in: U. Veit - T. L. Kienlin - C. Kümmel - S. Schmidt (eds.), Spuren und Botschaften. Interpretationen materieller Kultur (Münster 2003) 29-51

Hahn 2005: H. P. Hahn, Materielle Kultur. Eine Einführung (Berlin 2005)

Hahn 2015: H. P. Hahn, Die geringen Dinge des Alltags. Kritische Anmerkungen zu einigen Trends der aktuellen Material Culture Studies, in: K. Braun - C.-M. Dieterich - A. Treiber (eds.), Materialisierung von Kultur. Diskurse, Dinge, Praktiken (Würzburg 2015) 28-42

Hallett 2015: C. H. Hallet, Defining Roman Art? in: B. E. Borg (ed.), A Companion to Roman Art (Chichester 2015) 11-33

Hardiman 2012: C. Hardiman, 'Popular’ Aesthetics and Personal Art Appreciation, in: I. Sluiter - R. M. Rosen (eds.), Aesthetic Value in Classical Antiquity (Leiden 2012) 265-283

Hartmann - Haubl 2000: H. Hartmann - R. Haubl, Von Dingen und Menschen. Eine Einführung, in: H. Hartmann R. Haubl (eds.), Von Dingen und Menschen. Funktion und Bedeutung materieller Kultur (Wiesbaden 2000) 7-12

Haug 2020: A. Haug, Decor-Räume in pompejanischen Stadthäusern. Ausstattungsstrategien und Rezeptionsformen, DECOR 1 (Berlin 2020)

von Hesberg 1980: H. von Hesberg, Tischgräber in Italien, AA 1980, 422-439

von Hesberg 1981: H. von Hesberg, Girlandenschmuck der republikanischen Zeit in Mittelitalien, RM 88, 1981, 201-245

Heufler 2016: G. Heufler, Design Basics. Von der Idee zum Produkt (Zurich 2016)

Hielscher, forthcoming: A. Hielscher, Pompejanische Kleinfunde und antikes Objektdesign. Untersuchungen zur decorativen Gestaltung römischen Hausinventars am Beispiel der Insula I 10, DECOR 4 (Berlin forthcoming)

Hildebrandt et al. 2014: B. Hildebrandt - G. Neuner - F. Schneider, Prestigegüter, in: S. Samida - M. K. H. Eggert H. P. Hahn (eds.), Handbuch Materielle Kultur. Bedeutungen, Konzepte, Disziplinen (Berlin 2014) 237-240

Hodder 1989: I. Hodder, This Is Not an Article About Material Culture as Text, Journal of Anthropological Archaeology 8, 1989, 250-269

Hölscher 2017: T. Hölscher, Die Geschöpfe des Daidalos. Vom sozialen Leben der griechischen Bildwerke (Heidelberg 2017)

Iser 2003: W. Iser, Von der Gegenwärtigkeit des Ästhetischen, in: J. Küpper - C. Menke (eds.), Dimensionen ästhetischer Erfahrung (Frankfurt a. M. 2003) 176-202

Kalthoff et al. 2016: H. Kalthoff - T. Cress - T. Röhl, Einleitung. Materialität in Kultur und Gesellschaft, in: H. Kalthoff - T. Cress - T. Röhl (eds.), Materialität. Herausforderungen für die Sozial- und Kulturwissenschaften (Paderborn 2016) 11-41

Keßeler 2016: A. Keßeler, Affordanz, oder was Dinge können, in: K. P. Hofmann - T. Meier - D. Mölders - S. Schreiber (eds.), Massendinghaltung in der Archäologie. Der Material Turn und die Ur- und Frühgeschichte (Leiden 2016) 343-363

Kienlin 2005: L. Kienlin, Die Dinge als Zeichen. Zur Einführung in das Thema, in: T. L. Kienlin (ed.), Die Dinge als Zeichen. Kulturelles Wissen und materielle Kultur (Bonn 2005) 1-20

Kienlin - Widura 2014: T. L. Kienlin - A. Widura, Dinge als Zeichen, in: S. Samida - M. K. H. Eggert - H. P. Hahn (eds.), Handbuch Materielle Kultur. Bedeutungen, Konzepte, Disziplinen (Stuttgart 2014) 31-38

Klatt 1995: U. Klatt, Römische Klapptische. Drei- und Vierbeinige Stützgestelle aus Bronze und Silber, KölnJb 28, 1995, 349-573

Kleimann 2002: B. Kleimann, Das ästhetische Weltverhältnis. Eine Untersuchung zu den grundlegenden Dimensionen des Ästhetischen (Munich 2002)

Knappett 2004: C. Knappett, The Affordances of Things. A Post-Gibsonian Perspective on the Relationality of Mind and Matter, in: E. DeMarrais - C. Gosden - C. Renfrew (eds.), Rethinking Materiality. The Engagement of Mind with the Material World (Exeter 2004) 43-51

Kunze 2008: C. Kunze, Zwischen Griechenland und Rom. Das ,antike Rokoko“ und die veränderte Funktion von Skulptur in späthellenistischer Zeit, in: K. Junker - A. Stähli (eds.), Original und Kopie. Formen und Konzepte der Nachahmung (Wiesbaden 2008) 77-108

Lang 2016: J. Lang, Ornamentale Grenzfälle. Zur Semantik pflanzlichen Dekors in der unteritalischen Vasenmalerei, in: C. Lang-Auinger - E. Trinkl (eds.), ФYTA KAI ZSIA. Pflanzen und Tiere auf griechischen Vasen, CVA Österreich Beih. 2 (Vienna 2016) 189-200

Lang 2017: J. Lang, Ornament versus Figur. Zur Lesbarkeit von Formgebungen am Beispiel italischer Sigillata, in: M. Flecker (ed.), Neue Bilderwelten. Zur Ikonographie und Hermeneutik Italischer Sigillata (Rahden 2017) 161-173 Lapatin 2015: K. Lapatin, Luxury Arts, in: B. E. Borg (ed.), A Companion to Roman Art (Chichester 2015) 321-343 Lehmann 2016: H. Lehmann, Ästhetische Erfahrung. Eine Diskursanalyse (Paderborn 2016)

Liessmann 1999: K. P. Liessmann, Philosophie der modernen Kunst (Munich 1999)

Maase 2007: K. Maase, Nützlich? Angenehm? Schön? Überlegungen zur Ästhetik im Alltag, in: K. Eibel - K. Mellmann - R. Zymner (eds.), Im Rücken der Kulturen (Paderborn 2007) 89-111

Maischberger 1997: S. Maischberger, Marmor in Rom. Anlieferung, Lager- und Werkplätze in der Kaiserzeit (Wiesbaden 1997) 
Maiuri 1927: A. Maiuri, Relazione sui i lavori di scavo dal marzo 1924 al marzo 1926, NSc 1927, 3-116

Maiuri 1951: A. Maiuri, La casa a Pompei (Naples 1951)

Maiuri 1958: A. Maiuri, Ercolano. I nuovi scavi (1927-1958) (Rome 1958)

Maschek 2008: D. Maschek, Figur und Ornament. Das Tänzerinnenmonument von der Via Prenestina und die Produktion von Architekturdekor im römischen Suburbium des 1. Jhs. v. Chr., ÖJh 77, 2008, 185-217

Mau 1879: A. Mau, Scavi di Pompei, Bdl 1879, 193-210

Mazois 1824: C. Mazois, Les ruines de Pompéi II (Paris 1824)

Mendel 1914: G. Mendel, Catalogue des sculptures grecques, romaines et byzantines III (Constantinople 1914)

Mersch 2001: D. Mersch, Aisthetik und Responsivität. Zum Verhältnis von medialer und amedialer Wahrnehmung, in: E. Fischer-Lichte - C. Horn - S. Umathum - M. Warstat (eds.), Wahrnehmung und Medialität (Tübingen 2001) 273-300

Mols 1999: S. T. A. M. Mols, Wooden Furniture in Herculaneum. Form, Technique and Function (Amsterdam 1999)

Moss 1988: C. F. Moss, Roman Marble Tables (Ph.D. diss. Princeton University 1988)

Murray 1990: O. Murray, Sympotica. A Symposium on the Symposion (Oxford 1990)

Mustilli 1950: D. Mustilli, Botteghe di scultori, marmorarii, bronzieri e caelatores in Pompei, in: A. Maiuri (ed.), Raccolta di studi per il secondo centenario degli scavi di Pompei (Naples 1950) 206-229

Nissen 1877: H. Nissen, Pompejanische Studien (Leipzig 1877)

Norman 2013: D. Norman, The Design of Everyday Things (New York 2013)

Oenbrink 1997: W. Oenbrink, Das Bild im Bilde. Zur Darstellung von Götterstatuen und Kultbildern auf griechischen Vasen (Frankfurt a. M. 1997)

Pernice 1932: E. Pernice, Hellenistische Tische, Zisternenmündungen, Beckenuntersätze, Altäre und Truhen. Die hellenistische Kunst in Pompeji V (Berlin 1932)

Raff 2008: T. Raff, Die Sprache der Materialien. Anleitung zu einer Ikonologie der Werkstoffe ${ }^{2}$ (Munich 2008)

Reinhardt 2018: N. Reinhardt, Material und Design. Untersuchung zu einem materialorientierten Gestaltungsansatz (Bielefeld 2018)

Reinhardt 2018a: A. Reinhardt, Delectari varietate. Zur Erklärung der repetitiven Darstellung auf dem ,Puteal Tegel‘, in: N. Dietrich - M. Squire (eds.), Ornament and Figure in Graeco-Roman Art. Rethinking Visual Ontologies in Classical Antiquity (Berlin 2018) 299-326

Richter 1966: G. M. A. Richter, The Furniture of the Greeks, Etruscans and Romans (London 1966)

Romanelli 1811: D. Romanelli, Viaggio a Pompei, a Pesto e di ritorno ad Ercolano ed a Pozzuoli (Naples 1811)

Schefold 1934: K. Schefold, Statuen auf Vasenbildern, Jdl 52, 1934, 30-75

Scholz 2019: J. Scholz, Die Präsenz der Dinge. Anthropomorphe Artefakte in Kunst, Mode und Literatur (Bielefeld 2019)

Seel 1996: M. Seel, Ethisch-ästhetische Studien (Frankfurt a. M. 1996)

Sievers 1938: H. Sievers, Beiträge zur Wirtschaftsgeschichte Pompejis (Hamburg 1938)

Sinn 2015: F. Sinn, Decorative Art, in: B. E. Borg (ed.), A Companion to Roman Art (Chichester 2015) 301-321

Sogliano 1900: A. Sogliano, Relazione degli scavi eseguiti durante il mese di maggio 1900, NSc 1901, 155-212

Sogliano 1905: A. Sogliano, Relazione degli scavi fatti dal dicembre 1902 a tutto marzo 1905, NSc 2, 1905, 245-257

Spano 1910: G. Spano, Pompei. Reazione degli scavi eseguiti dal marzo 1905 a tutto dicembre 1906, NSc 7, 1910, 253-282

Spinazzola 1953: V. Spinazzola, Pompei alla luce degli scavi nuovi (Rome 1953)

Squire 2018: M. Squire, 'To Haunt, to Startle, and Way-Lay'. Approaching Ornament and Figure in Graeco-Roman Art, in: N. Dietrich - M. Squire (eds.), Ornament and Figure in Graeco-Roman Art. Rethinking Visual Ontologies in Classical Antiquity (Berlin 2018) 1-36

Steffen 2000: D. Steffen, Design als Produktsprache. Der ,Offenbacher Ansatz‘ in Theorie und Praxis (Frankfurt a. M. 2000)

Swift 2009: E. Swift, Style and Function in Roman Decoration. Living with Objects and Interiors (Burlington, VT 2009)

Swift 2014: E. Swift, Design, Function and Use-Wear in Spoons. Reconstructing Everyday Roman Social Practice, JRA 27, 2014, 203-237

Swift 2017: E. Swift, Roman Artefacts and Society. Design, Behaviour, and Experience (Oxford 2017)

Vinci 1831: G. Vinci, Descrizione delle ruine di Pompeii ${ }^{3}$ (Naples 1831)

de Vos 1982: M. de Vos, Pompei, Ercolano, Stabia (Rome 1982)

Wagner 2005: ÄGB III (2005) 866-882 s.v. Material (M. Wagner)

Wallace-Hadrill 2008: A. Wallace-Hadrill, Rome's Cultural Revolution (New York 2008)

Wolf 2019: G. Wolf, Die Vase und der Schemel. Ding, Bild oder eine Kunstgeschichte der Gefäße (Dortmund 2019) 
